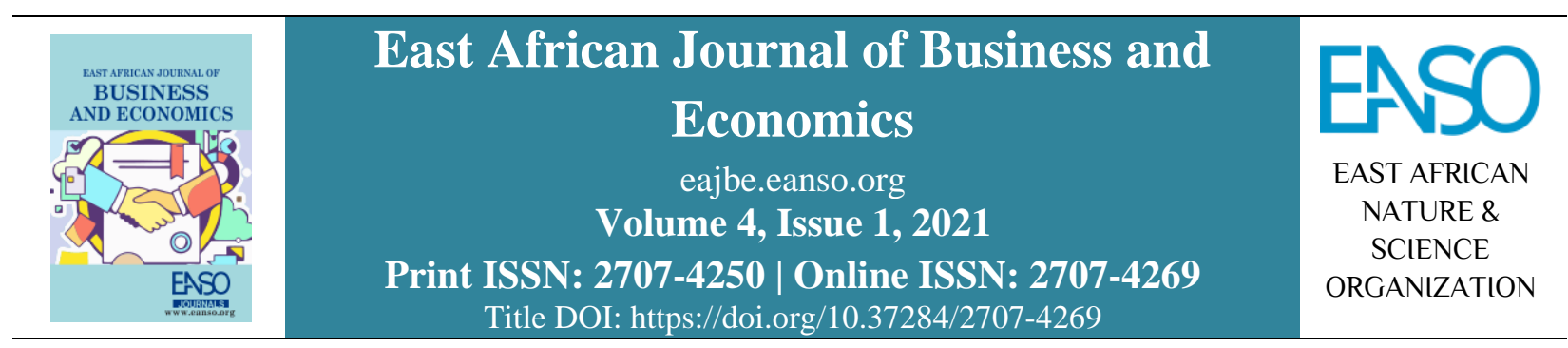

Original Article

\title{
Assessment of the Determinants of Balance of Payment in Tanzania.
}

\author{
Magreth Exuper Kingia ${ }^{1 *} \&$ Dr. Seif Muba \\ ${ }^{1}$ Mzumbe University Tanzania, P. O. Box 1 , Morogoro, Tanzania. \\ *Correspondence email: magreth.kingia19@mustudent.ac.tz
}

Article DOI: https://doi.org/10.37284/eajbe.4.1.485

\section{Date Published: ABSTRACT}

26 November 2021 The purpose of the study was to assess the determinants of the balance of payment in Tanzania. The nature of this study was quantitative where

Keywords: secondary time series data covering a period of thirty-one years between 1990 and 2020 were collected. The study performed descriptive statistics

Balance of Payment, Exchange Rate,

Foreign Direct Investment,

Interest Rate, Inflation Rate. and diagnostic tests such as normality test, unit root test for stationarity, Pearson's Correlation matrix to check if there is a multicollinearity problem in the data. The diagnostic tests revealed that the data bring unbiased results, therefore the ordinary least square regression was performed and we found that foreign direct investment and inflation rate have a negative and significant influence on the balance of payment, whereas exchange rate has a positive and insignificant influence on the balance of payment, and the interest rate has an insignificant negative influence on the balance of payment. Finally, we recommend that a country have to introduce relative prices of imports in order to improve the inflows of FDI in order to have a favourable balance of payment in a country like Tanzania. Also, Tanzania's central bank must be cautious in its monetary policy and take some beneficial steps to regulate the money supply. To attract the new internal investor, it must keep an eye on interest rates and charge a low-interest rate.

\section{APA CITATION}

Kingia, M. E., \& Muba, S. (2021). COVID 19 Assessment of the Determinants of Balance of Payment in Tanzania. East African Journal of Business and Economics, 4(1), 62-75. https://doi.org/10.37284/eajbe.4.1.486

\section{CHICAGO CITATION}

Kingia, Magreth Exuper. \& Seif Muba. 2021. "Assessment of the Determinants of Balance of Payment in Tanzania”. East African Journal of Business and Economics 4 (1), 62-75. https://doi.org/10.37284/eajbe.4.1.486.

\section{HARVARD CITATION}

Kingia, M. E., \& Muba, S. (2021) “Assessment of the Determinants of Balance of Payment in Tanzania”, East African Journal of Business and Economics, 4(1), pp. 62-75. doi: 10.37284/eajbe.4.1.486.

$62 \mid$ This work is licensed under a Creative Commons Attribution 4.0 International License. 


\section{IEEE CITATION}

M. E. Kingia, \& S. Muba, "Assessment of the Determinants of Balance of Payment in Tanzania”, EAJBE, vol. 4, no. 1, pp. 6275, Nov. 2021.

\section{MLA CITATION}

Kingia, Magreth Exuper. \& Seif Muba. “Assessment of the Determinants of Balance of Payment in Tanzania”. East African Journal of Business and Economics, Vol. 4, no. 1, Nov. 2021, pp. 62-75, doi:10.37284/eajbe.4.1.486.

\section{INTRODUCTION}

The authors of Post-Keynesian economics have highlighted in recent decades that a country's balance of payments requires more attention since it contains aspects that can either support or hinder growth (Davidson, 1990). When Frenkel \& Mussa (1985) looked at growth in global monetary economics, they noticed that the issue of balance of payment is treated as a primary concern rather than a secondary concern in policy management. The balance of payment gives detailed information on the demand for and supply of a country's currency, and it plays a crucial part in the economy's development (Mushendami et al., 2017). The balance of payment position is often utilised as a global indicator of a country's performance in the global economy.

The balance of payment (BOP) of a country is very important because it measures the country's strength because it accounts for the country's import of goods and services and acts as a guide for some domestic policies. The BOP also reveals/ accounts for the country's transactions relating to payments received (for exports of services and goods), financial transfers, financial capital, and so on for a given time period. The stability in the balance of payments is the basic macroeconomic goal that all economies try to accomplish globally (Aidi et al., 2018). As a result, in order to maintain this balance, governments place a premium on economic policy implementation that reduces the amount spent on imports while increasing exports to foreign markets (Mwai, 2015). Those that apply these macroeconomic policies produce a long-term balance of payment stability; on the other hand, countries that do not execute these policies experience deficits and inverse BOP growth.

Tanzania is a developing country that is heavily reliant on imports of products and services to meet local consumption/demands due to a lack of a strong manufacturing base to create industrial goods and services for export to keep up with rising imports. As a result, the total value of imports often exceeds the entire value of exports; this condition is likely to generate disequilibrium/instability in a country's balance of payment. Post-Keynesians have suggested that inflationary processes and the exchange rate can explain the balance of payments in this regard (Vernengo, 2003).

Tanzania's balance of payments has continued to deteriorate over time. Meanwhile, macroeconomic factors may be one of the key causes of this deterioration; scholars believe there is a link between these variables (inflation, Foreign Direct Investment, interest rate, exchange rate, and balance of payment). While successive Tanzanian governments have made numerous efforts to ensure that the balance of payments is in equilibrium/stable, the researchers are correct in stating that the issues are far from being resolved. Aside from this backlog, the goal of this study is to evaluate the factors of Tanzania's balance of payment.

\section{Contribution of the Study}

The elements that determine the balance of payments have been examined by a number of experts and intellectuals from throughout the world. And also, there are several theories that state the concept of balance of payment (BOP), each of which has its own interpretation of BOP. As a result, 
this section displays the theories and research conducted by a number of academics on a variety of macroeconomic topics to demonstrate the gaps in the current body of literature in order to justify the research's undertaking and activity.

\section{THEORETICAL REVIEW}

Absorption Approach to BOP: The balance of trade is defined as the difference between total domestic expenditure (absorption) and total domestic revenue in this theory. The focus of this idea was on how local expenditure on domestic goods changed over time in relation to the local output. The focus of this theory is on the current account and balance of trade. According to this theory, the trade balance is equivalent to the difference between domestic income and total absorption. As a result, it can be determined that if total expenditure (absorption) exceeds output (income), imports will exceed exports, resulting in a BOP deficit, and if absorption exceeds income, the BOP will be in surplus. (Alexander, 1952). The Elasticity Approach to BOP: This method clearly demonstrates how a change in the exchange rate can affect trading terms. According to the elasticity theory, the BOP's current account can be modified by the foreign exchange rate (Eita \& Gaomab, 2012). Monetary Approach to Balance of Payment: According to Kemp (1975), this theory does not imply that changes in the money supply are the only factor influencing the BOP. The monetary approach to BOP revolves around the monetary account deficit, which includes factors that affect the domestic monetary base Ardalan (2003). This method emphasises the BOP's monetary characteristics, looks beyond the stock market and considers the importance of financial assets (Melvin, 1992). The money supply is viewed as endogenous in this theory, with the BOP responding to the central bank's monetary liabilities adjustments through changes in international reserves. Interest Rate Parity Theory (IRP): The IRP theory assumes that spot exchange rate variations are caused by foreign investors' actions, which are motivated by differences in the rate of return on equivalent assets from one country to the next. Furthermore, the IRP implies that the nation's financial account activities have an impact on the rate of exchange value on the foreign currency market. Purchasing Power Parity Theory: This theory is based on the expansion and variation of the one-price rule (Devereux \& Engel, 2003). When the good price is not the same in two countries' markets due to excessive inflation, people are more motivated to make money by buying things at a low price and selling at a high price.

\section{EMPIRICAL REVIEW}

\section{Exchange Rate and Balance of Payment}

Imoisi (2015) presented that the government should increase capital spending so as to stimulate exports through the Nigerian economy diversification. Another empirical study by Sangeetha \& Patni (2018) who led an examination on the factors that determine the balance of payment in the US and India argued that in India the balance of payment is influenced by the exchange rate. In the USA, the balance of payment is affected by the rate of exchange. However, Oladipupo \& Onotaniyohuwo (2011) came with the results that the rate of exchange is significantly and negatively associated with the balance of payments. Whereby Mwai (2015) indicated that the balance of payment would rise in response to the increase of the exchange rate.

Therefore, based on the previous research, this study examines the effect of the exchange rate on the balance of payment. Therefore, our first hypothesis is as follows;

\section{H1: Exchange rate has a significant negative} influence on the balance of payment.

\section{Foreign Direct Investment and Balance of Payment}

There is no consensus in prior studies regarding the effect of foreign direct investment on the balance of 
payment. A recent study by UKEssays (2018) showed that foreign direct investment improves the level of a country's trade output and accelerates development, according to the report. It also stated that foreign direct investment has an impact on Pakistan's balance of payments. Some of the other studies supported that that there is a positive and significant association between foreign direct investment and balance of payment Alencar \& Strachman (2012); Osoro (2013). According to Yousaf et al. (2008), exports have a negative relationship with FDI in the short run, but this negative relationship changes to a positive relationship in the long run for Pakistan. However, a study by Sezgin \& Özkan (2015) applied the econometric system to investigate how the balance of payment affected foreign direct investment in Turkey and resulted that balance of payment is not affected by foreign direct investment in Turkey. Selma \& Kastrati (2013) demonstrated that FDI had a positive impact on the BOP in both developed and developing countries. Thus, based on the prior studies, this study examines the effect of foreign direct investment on the balance of payment. Therefore, our second hypothesis is as follows;

H2: Foreign direct investment has a significant negative influence on the balance of payment.

\section{Inflation Rate and Balance of Payment}

Sangeetha \& Patni (2018) investigated the elements that influence the balance of payments in the United States and India. The findings of this study revealed that inflation has an impact on India's balance of payments. In the United States, the rate of inflation has an impact on the balance of payments. A study by Mwai (2015) concluded that inflation rate and balance of payment have a direct (positive) relationship in Kenya. Also, Shafi et al. (2015) showed that inflation has a positive impact on the balance of payment. On the other hand, Yousif \& Musa (2017) discovered that the inflation rate has a negative influence on the balance of payments. Aidi et al. (2018) revealed that the inflation rate has a significant negative effect on the balance of payment.

Therefore, based on the prior research, this study examines the effect of the inflation rate on the balance of payment. Therefore, our third hypothesis is as follows;

H3: Inflation rate has a significant negative influence on the balance of payment.

\section{Interest rate and Balance of Payment}

Sangeetha \& Patni (2018) studied the factors that influence the balance of payment in the United States and India. The findings revealed that the balance of payment in India is unaffected by interest rates. The rate of interest has an impact on the balance of payment in the United States. Eita \& Gaomab (2012), the results of this analysis revealed that the rate of interest has a considerable and direct impact on Namibia's Balance of Payments. The researchers concluded that the rate of interest improves the balance of payment in Namibia based on the findings. Yousif \& Musa (2017); Shafi et al. (2015) argued that interest rates have a negative impact on the balance of payments. On the other side, Aidi et al. (2018) indicated that interest rate does not have any impact on the balance of payment. Inversely, Mwai's (2015) findings concluded that the rate of interest and BOP have a positive relationship in Kenya.

Therefore, based on the prior research, this study examines the effect of interest rates on the balance of payment. Therefore, our fourth hypothesis is as follows;

H4: Interest rate has a significant negative influence on the balance of payment. 


\section{METHODOLOGY AND ESTIMATION TECHNIQUES}

To examine the determinants of the balance of payment in Tanzania, we extended the econometric estimation model. For a single equation model, the Ordinary Least Squares (OLS) method was employed as the estimation strategy. The OLS approach was chosen for this investigation because of the numerous benefits it provides (Wallace \& Silver, 1988). Sufficiency, lowest variance, Best Linear Unbiasedness (BLU), Least Mean Square Error (MSE), and efficiency are only a few of the significant advantages. Under this study, the balance of payment is the dependent variable, while FDI, interest rate, inflation rate, and exchange rate are the explanatory variables. Whereas variables such as foreign debt and money supply are variables to be controlled. This study adopted the ordinary least square model as shown below:

$$
\begin{aligned}
& Y=\beta 0+\beta 1 X 1+\beta 2 X 2+\beta 3 X 3+\beta 4 X 4+ \\
& \beta 5 X 5+\beta 6 X 6+\mu
\end{aligned}
$$

Where $\mathrm{X}_{1}$ stands for the exchange rate, $\mathrm{X}_{2}$ stands for Foreign Direct Investment, $X_{3}$ stands for the inflation rate, $\mathrm{X}_{4}$ stands for interest rate, $\mathrm{X}_{5}$ stands for Foreign Debt, $\mathrm{X}_{6}$ stands for Money Supply and $\mu$ stands for the error term.

\section{Unit Root Test}

A prerequisite for time series analysis is to perform a Unit Root Test to establish the integration sequence. To determine the order of integration, this study used the Augmented Dickey-Fuller (ADF) unit root tests for each series. The stationarity test was used in this work to help avoid the problem of inconsistent and false regression results (Rubinfeld \& Pyndick, 1998). The Unit Root Test's Null Hypothesis claims that the variable is nonstationary, whereas the alternative hypothesis states that it is stationary. In view of Wei (2006), the ADF test employs the following regression model:

$$
\Delta Y t=\beta 1+\beta 2 t+\delta Y t-1+\sum i=1 k \infty i \Delta Y t-
$$

$i+\varepsilon t$

[ii]

Where $\Delta=$ the first difference operator; $\Delta \mathrm{Yt}-\mathrm{i}=$ lagged values of the dependent variable, for example, $\Delta \mathrm{Yt}-1=(\mathrm{Yt}-1-\mathrm{Yt}-2), \Delta \mathrm{Yt}-2=(\mathrm{Yt}-2$ - Yt-3), and so forth; $\varepsilon t$ is a white noise error term; $\beta 1$ is a constant; $\beta 2$ is a slope coefficient on-time trend $\mathrm{t}$; $\delta$ is a coefficient of lagged $\mathrm{Yt}-1$, and $\mathrm{Yt}$ is the balance of payment.

\section{Normality Test}

The Shapiro Wilk test was used in this investigation to determine if the data were normally distributed. This aids in determining whether the sample/selected data are derived from a regularly distributed population. The null hypothesis of the Shapiro Wilk test for normal data is that the data are normally distributed, while the alternative hypothesis is that the data are not normally distributed, according to Hanusz et al. (2016).

\section{Multicollinearity Test}

Multicollinearity is a prevalent problem in timeseries data, and it occurs when two explanatory variables are linearly connected. This issue can result in incorrect sign magnitudes and coefficient estimates. As a result, Dohoo et al. (1997) stated that the multicollinearity test should be used to determine the accuracy of the explanatory variables in order to prevent findings uncertainty. Accordingly, the Pearson correlation matrix for the multicollinearity test was used in this investigation.

\section{FINDINGS}

\section{Descriptive Statistics}

The results of descriptive statistics as shown in Table 1 below, shows that with a standard deviation of 1.47USD Billions, the average balance of payment (BOP) was -1.63USD Billions. The smallest and largest numbers are -5.06 USD Billions and -45.8 USD Millions, respectively. Indicating a 
high negative change in a country, which could be due to the impact of excessive imports on BOP. The negative skewness of -1.19 indicates that the BOP is negatively skewed. The value of Kurtosis 3.19 indicates a high amount of economic risk in the distribution. For the exchange rate, the standard deviation is 653.74TZS/1USD, and the average exchange rate is $1186.73 \mathrm{TZS} / 1 \mathrm{USD}$. The difference between the average value and the standard deviation suggests that the exchange rate fluctuated over the study period since the mean value of EXR is high and far from the standard deviation. During the study period, the lowest EXR value was 195.06 TZS/1USD, while the highest was 2319.03 TZS/1USD. The skewness of .33 shows a positively skewed exchange rate, and the Kurtosis of 2.05 suggests a considerable level of economic risk in the distribution.

The FDI inflow has the largest value is $5.66 \%$ while the average value is $2.54 \%$ and the Standard deviation is 1.54 that is lower than the average value. The FDI skewness value is .18, showing FDI is positively skewed, the value of Kurtosis is 2.25. The average rate of inflation is 12.08 percent, with a standard deviation of 9.55 percent. The standard deviation of inflation is low and far from the average value, indicating a substantial fluctuation in the rate of inflation from 1990 to 2020. The lowest and highest inflation rates are $3.46 \%$ and $35.83 \%$, respectively. Inflation has a skewness of 1.19, showing the inflation rate is positively skewed; the value of Kurtosis is 3.19 .

The average value of the interest rate is 6.34 percent, and a standard deviation of 6.91 percent. However, the lowest and highest interest rates are $-26.49 \%$ and $14.52 \%$, respectively, indicating that the interest rate has a large long-term fluctuation between 1990 and 2020, which could be influenced by changes in economic policies, tax reforms, and other factors. The negative skewness of -3.54 implies that interest rates are negatively skewed; the Value of Kurtosis is 17.79 suggesting a distribution with more outliers than normal. The largest amount of foreign debt (FD) to the country was 61.8 USD Billions and the smallest amount was 4.07 USD Billions while the average amount is 25.1 USD Billions and the standard deviation is 19.1 USD Billions that is lower than the average amount. FD has a skewness value of .59 and the value of Kurtosis of 1.97. The smallest and largest values of money supply are 165 USD Billion and 30.3 USD Trillions, respectively. Money supply (MS) has an average value of 8.95 USD Trillions and a standard deviation of 9.81 USD Trillions. The money supply is positively skewed as shown by the skewness of .89. Also, MS has the Kurtosis value of 2.34 .

Table 1: Descriptive statistics results

\begin{tabular}{llllllll}
\hline Variable & Obs. & Mean & Std. Dev. & Min & Max & Skewness & Kurtosis \\
\hline BOP & 31 & -1.63 & 1.47 & -5.06 & -45.8 & -1.19 & 3.19 \\
EXR & 31 & 1186.73 & 653.74 & 195.06 & 2319.03 & .33 & 2.05 \\
FDI & 31 & 2.54 & 1.54 & .00 & 5.66 & .18 & 2.25 \\
INF & 31 & 12.08 & 9.55 & 3.46 & 35.83 & 1.19 & 3.19 \\
INT & 31 & 6.34 & 6.91 & -26.49 & 14.52 & -3.54 & 17.79 \\
FD & 31 & 25.1 & 19.1 & 4.07 & 61.8 & .59 & 1.97 \\
MS & 31 & 8.95 & 9.81 & 165 & 30.3 & .89 & 2.34 \\
\hline BOP = balance of payment; EXR = Exchange rate; FDI = Foreign direct investment; INF $=$ Inflation \\
rate; INT = Interest rate; FD = Foreign Debt; MS = Money supply
\end{tabular}


Prepared by a researcher with data from the World Bank Group and Central Bank of Tanzania

\section{Pre-Estimation Results}

Since this study used time-series data, it was required to check for data stationarity before continuing to an assessment of the regression analysis. Standard practices in the time series literature propose that the researcher first verifies for a unit root in the series before doing equation estimation. The rule is that in the Null hypothesis, there is a unit root and Alternative hypothesis, there is no unit root, meaning that data are stationary. The results of the unit root test are shown in Table 2 below. Augmented Dickey-Fuller (ADF). At the zero level of difference, the equivalent $p$-value of the balance of payment and interest rate was less than 0.05. This means that we reject the null hypothesis, which asserts that the data is nonstationary and accept the alternative hypothesis, which argues that the Balance of Payments and interest rate does not have a unit root at the level (Stationary). The corresponding p-values of the exchange rate, FDI, inflation rate, foreign debt, and money supply at zero level of difference were greater than 5\%, respectively indicating data is nonstationary. Then we converted exchange rate, FDI, inflation rate, foreign debt, and money supply into the first difference where the $\mathrm{p}$ values became less than 0.05 (Table 2). This means we reject the null hypothesis, which states that the data is nonstationary and accept the alternative hypothesis, meaning that exchange rate, FDI, inflation rate, foreign debt, and money supply do not have a unit root at level (Stationary).

Table 2: Unit root test (Augmented Dickey Fuller (ADF)) test results

\begin{tabular}{|c|c|c|c|c|}
\hline Variable & $\begin{array}{l}\text { ADF } \\
\text { Test Statistic }\end{array}$ & $\begin{array}{l}5 \% \text { Critical } \\
\text { Value }\end{array}$ & $\begin{array}{l}\text { P Value } \\
\text { (0) }\end{array}$ & $\begin{array}{l}\text { P Value } \\
\text { (1) }\end{array}$ \\
\hline Balance of Payment (BOP) (0) & -4.324 & -2.986 & 0.000 & \\
\hline Exchange Rate (EXR) (1) & -3.824 & -2.986 & 0.140 & 0.001 \\
\hline Foreign Direct Investment (FDI) (1) & -3.691 & -2.986 & 0.068 & 0.000 \\
\hline Inflation rate (1) & -3.716 & -2.986 & 0.071 & 0.031 \\
\hline Interest rate $(0)$ & -4.962 & -2.986 & 0.048 & \\
\hline Foreign Debt (1) & -4.391 & -2.986 & 0.997 & 0.002 \\
\hline Money supply (1) & -5.991 & -2.986 & 1.000 & 0.004 \\
\hline
\end{tabular}

Prepared by researcher with data from the World Bank Group and Central Bank of Tanzania (BOT)

The study also performed the normality test to see if a data set was normally distributed and to calculate the likelihood that a random variable underlying the data set was normally distributed. The researchers used the Shapiro Wilk test for three-parameter lognormal data to see if the data for the analysis was normally distributed in a population. The Shapiro Wilk test's null hypothesis is that the data are normally distributed, whereas the alternative hypothesis is that they aren't (Shapiro \& Francia,
1965). The results of this analysis, as shown in Table 3 below, show that the Null Hypothesis cannot be rejected because the Shapiro significance values for the balance of payments, exchange rate, foreign direct investment, inflation, and interest rate are all greater than 0.05 , indicating that the data is normally distributed. According to Shapiro \& Francia (1965), if it is less than 0.05, the data is significantly different from the normal distribution. 
Table 3: Normality test results as per Shapiro Wilk test

\begin{tabular}{llllll}
\hline Variable & Obs. & W & V & $\mathbf{z}$ & Prob>z \\
\hline $\boldsymbol{B O P}$ & 31 & 0.81837 & 5.916 & 3.683 & 0.08201 \\
$\boldsymbol{E X \boldsymbol { R }}$ & 31 & 0.94335 & 1.845 & 1.269 & 0.10143 \\
$\boldsymbol{F D I}$ & 31 & 0.97576 & 0.789 & -0.490 & 0.69045 \\
$\boldsymbol{I N \boldsymbol { F }}$ & 31 & 0.80291 & 6.420 & 3.853 & 0.09643 \\
$\boldsymbol{I N T}$ & 31 & 0.62070 & 12.355 & 5.209 & 0.78223 \\
$\boldsymbol{F D}$ & 31 & 0.88486 & 3.751 & 2.739 & 0.30821 \\
$\boldsymbol{M S}$ & 31 & 0.82084 & 5.836 & 3.655 & 0.13201 \\
\hline
\end{tabular}

Prepared by researcher with data from the World Bank Group and Central Bank of Tanzania (BOT)

This study also performed the multicollinearity test. According to Dohoo et al. (1997), the multicollinearity test is necessary to determine the accuracy of the explanatory factors and avoid findings uncertainty. As a result, the Pearson correlation matrix for the multicollinearity test was used in this investigation. A multicollinearity problem occurs when one or more independent variables have a high correlation and can accurately predict one another. Multicollinearity occurs when the correlation index is more than 0.75 in absolute terms (Lin, 2008). As a result, in order to determine whether or not there is a multicollinearity problem, this study used a Pearson correlation. Because the explanatory variables had a modest association, as shown in Table 4, it suggests that multicollinearity issues were either non-existent or mild. As a result, in the subsequent study, all explanatory variables were used.

Table 4: Pearson Correlation results

\begin{tabular}{llllllll}
\hline VARIABLE & $\boldsymbol{B O P}$ & $\boldsymbol{E X R}$ & $\boldsymbol{F D I}$ & $\boldsymbol{I N F}$ & $\boldsymbol{I N T}$ & $\boldsymbol{F D}$ & $\boldsymbol{M S}$ \\
\hline $\boldsymbol{B O P}$ & 1.0000 & & & & & & \\
$\boldsymbol{E X \boldsymbol { R }}$ & $-0.5475^{*}$ & 1.0000 & & & & & \\
$\boldsymbol{F D I}$ & $-0.4202^{*}$ & 0.2171 & 1.0000 & & & & \\
$\boldsymbol{I N \boldsymbol { F }}$ & 0.2501 & $-0.3120^{*}$ & $-0.4896^{*}$ & 1.0000 & & & \\
$\boldsymbol{I N T}$ & -0.0399 & 0.1911 & -0.2902 & 0.0163 & 1.0000 & & \\
$\boldsymbol{F D}$ & $-0.6189^{*}$ & $0.2701^{*}$ & 0.1630 & $-0.5220^{*}$ & 0.1929 & 1.0000 & \\
$\boldsymbol{M S}$ & $-0.5620^{*}$ & $0.5548^{*}$ & 0.0322 & $-0.5347^{*}$ & 0.2400 & $0.5840^{*}$ & 1.0000 \\
\hline
\end{tabular}

Prepared by researcher with data from the World Bank Group and Bank of Tanzania 
From the Pearson correlation matrix, as shown in Table 4, the results show that the Exchange Rate (EXR) has a moderate negative association with the balance of payments (BOP), with $r=-0.5475$. It is suggested that if the exchange rate rises, the balance of payment will decrease. This implies that a higher exchange rate worsens Tanzania's balance of payments situation. Foreign direct investment and balance of payments have a moderately negative connection $(r=-0.4202)$. Because of the direction of this relationship, a rise in FDI will result in a decrease in the BOP. It means that as FDI inflows rise, so do importations, worsening a country's balance of payments (BOP Instability) due to poor exports. The inflation rate and the balance of payments have a weak positive association $(r=$ 0.2501 ). Because of the direction of this association, an increase in the inflation rate will result in an increase in the balance of payment. This conclusion Table 5: Ordinary Least Square Results suggests that inflation has an impact on imports via the currency rate, resulting in large imports that affect the balance of payment deficit. The inflation rate and the BOP have a slight negative association $(r=-0.0399)$. Because of the direction of this relationship, an increase in interest rate will result in a decrease in the balance of payment. This conclusion suggests that a high-interest rate has an impact on imports by influencing the exchange rate, resulting in high imports that affect the BOP deficit.

\section{Regression Results}

This study used the Ordinary Least Square regression model to analyse the data. The balance of payments was the dependent variable in this study, with the exchange rate, foreign direct investment, inflation, and interest rate as explanatory variables.

\begin{tabular}{ll}
\hline Variables & Ordinary Least Square Model \\
\hline EXR & \\
Coefficient & 436644.6 \\
Std. Err & 1614461 \\
P-value & $(0.789)^{*}$ \\
\hline FDI & $-405,000,000$ \\
Coefficient & $184,000,000$ \\
Std. Err & $(0.038) * *$ \\
P-value & \\
\hline INF & $-94,200,000$ \\
Coefficient & $38,700,000$ \\
Std. Err & $(0.023) * *$ \\
P-value & \\
\hline INT & -8944250 \\
Coefficient & $27,300,000$ \\
Std. Err & $(0.746) *$ \\
P-value & \\
FD Coefficient & -.1861621 \\
Std. Err & .0824803 \\
P-value & $(0.033) * *$ \\
\hline MS $\quad$ \\
Coefficient & .0001985 \\
Std. Err & .0001835 \\
P-value & $(0.290) *$ \\
\hline cons & \\
\hline
\end{tabular}




\begin{tabular}{ll}
\hline \multicolumn{1}{c}{ Coefficient } & $2,960,000,000$ \\
Std. Err & $1,630,000,000$ \\
P-value & $(0.082) *$ \\
\hline R-square & 0.6695 \\
A-R square & 0.5869 \\
Number of Observations & 31 \\
F $(6,24)$ & 8.10 \\
Prob $>$ F & 0.0001 \\
\hline
\end{tabular}

Note: The dependent variable for this regression result is the Balance of Payment.

$* * * * * *$ denotes the significant level at 10\%, 5\%, and $1 \%$ respectively

The coefficient of determination is $58.69 \%$, as shown in Table 5. This means that exchange rates, foreign direct investment, inflation, and interest, as well as control factors like foreign debts and money supply, account for $58.69 \%$ of the volatility in the balance of payments. Other factors, such as gross domestic product, terms of trade, and trade openness may account for the remaining $41.31 \%$, according to these findings.

\section{The Influence of Exchange Rate on the Balance of Payment}

The result shown in Table 2 above reveals that the exchange rate has a positive and insignificant influence on the balance of payment. This indicates a direct relationship between the exchange rate and the balance of payment. From these findings, it was determined that the exchange rate has been increasing throughout the study period yet the balance of payment has been increasing in deficit. This could be influenced by inappropriate abuse and allocation of fiscal indiscipline and lack of suitable spending control regulations due to power centralisation in government. However, because the influence of the exchange rate on the balance of payment was not significant, this link may not have any economic implications. The findings of this study also agree with those of (Lotfalipour \& Bazargan, 2014; Odili, 2014), who found that the exchange rate has no impact on the balance of payment. Mwai (2015) also found a positive relationship between foreign exchange rates and BOP in Kenya. The findings of this analysis contradict those of Oladipupo \& Onotaniyohuwo (2011), who claimed that the rate of exchange is strongly and negatively related to Nigeria's balance of payments.

\section{The Influence of Foreign Direct Investment on the Balance of Payment}

The result shown in Table 2 above reveals that foreign direct investment has a negative and significant influence on the balance of payment. This indicates an indirect relationship between foreign direct investment and the balance of payment. This means that a rise in foreign direct investment in Tanzania leads to a reduction in the country's balance of payments. According to these findings, when FDI increases, so does the demand for the receiving nation's currency (Tanzania), raising the country's exchange rate. Furthermore, a rise in the country's currency improves the country's trade conditions. However, as the currency rises in value, so does its competitiveness, and exports may fall, aggravating the BOP. The findings of this study are similar to those of Yousaf et al. (2008), who found a negative long-term relationship for Pakistan. They came to the conclusion that Pakistan should provide a conducive environment for attracting foreign direct investment since it is more suitable for the import exchange business. These results contradict those of Alencar \& Strachman (2012), who suggested that when FDI rises, so does the balance of payments, and vice versa. Foreign direct investment (FDI) enhances a host country's imports and exports, according to (Amir \& 
Mehmood, 2012). The magnitude of export elasticity in regard to FDI, on the other hand, is greater than that of import elasticity in relation to FDI. As a result, while both imports and exports are increasing in lockstep with FDI, exports are growing faster than imports. As a result, FDI has an impact on BOP positively.

\section{The Influence of Inflation rate on the Balance of Payment}

The result reveals that the Inflation rate has a negative and significant influence on the balance of payment. This indicates an indirect relationship between the Inflation rate and balance of payment. This means that if the rate of inflation rises, so does the BOP in Tanzania. This result implies that rising inflation reduces overall nationwide output, resulting in a sharp drop in exports. Furthermore, the findings of this study suggest that Tanzania's declining balance of payments may be due to internal inflation, which increases import spending because imports appear to be relatively inexpensive and lower exports since exports look to be more expensive in a foreign country. The conclusions of this analysis agree with those of Yousif \& Musa (2017), who found that inflation had a negative impact on Sudan's balance of payments. Aidi et al. (2018) found a similar negative association between inflation and BOP in Nigeria, claiming that inflationary pressures reduce total national production, resulting in a dramatic drop in exports. These findings contradict those of Mwai (2015), who determined that the rate of inflation and the balance of payments in Kenya have a positive relationship. According to the study, an increase in the inflation rate will result in a corresponding increase in Kenya's balance of payment deficit. Supporting the PPP theory, which claims that when the price of an item differs between two nations' markets due to significant inflation, individuals are more motivated to seek profit by buying goods in the low-cost market and selling in the high-cost market.

\section{The Influence of Interest rate on the Balance of Payment}

The result reveals that the interest rate has a negative and insignificant influence on the balance of payment. This indicates an indirect relationship between the interest rate and the balance of payment. This means that an increase in Tanzania's interest rates leads to a decrease in the country's balance of payments. This connection, however, is insignificant. The statement contradicts the monetary approach to the balance of payment, which emphasises that a country's balance of payment is ultimately a monetary phenomenon (Frenkel \& Johnson, 1976). This finding is in line with Aidi et al. (2018) who discovered that interest rate has no effect on the balance of payment. Even if the coefficient's negative sign corresponds to a prior expectation, since a higher interest rate inhibits investment, this will have a long-term negative impact on output, exports, and the balance of payments, according to this study. These findings contradict those of Mwai (2015), who found a direct (positive) link between interest rate and BOP in Kenya. Shafi et al. (2015) discovered that interest rates have a negative and significant impact on the economy.

\section{CONCLUSION}

The study's findings reveal that the exchange rate has an insignificant positive influence on Tanzania's balance of payment, with the balance of payment increasing as the Tanzanian currency increases. However, because the link between EXR and BOP was statistically insignificant, this analysis implies that the exchange rate has no economic impact on Tanzania's balance of payments.

The analysis concludes that foreign direct investment has a negative impact on Tanzania's balance of payments, with the balance of payment decreasing as FDI increases. As FDI increases, so does the demand for the receiving nation's currency (Tanzania), raising the country's exchange rate. 
Furthermore, growth in the country's currency improves trading terms while also improving the country's balance of payments. Nonetheless, due to Tanzania's greater tendency to buy manufacturing inputs from outside the country, FDI contributes to the country's recurrent balance of payment deficits.

The analysis shows that inflation has a negative influence on Tanzania's balance of payments. Inferring that an increase in Tanzania's inflation rate results in a commensurate fall in the country's balance of payments.

According to the findings, interest rates have no effect on Tanzania's balance of payments. The negative relationship between interest rate and balance of payment means that when interest rates rise, the BOP falls. However, because the variable is not statistically significant in the study's model, no substantial economic implications can be drawn from it.

\section{Conclusion and Policy Implication}

This study suggests that a government should implement relative import prices in order to increase FDI inflows and maintain a good balance of payments in Tanzania. As a result, exports should not be outweighed by imports to avoid harming the country's balance of payments. In addition, the report suggests that relative export prices be improved to boost BOP. Furthermore, the study advises policymakers to find an alternative to public borrowing to support budget deficits or government projects, as this can help Tanzania's BOP deficit. Also, Tanzania's government should seek measures that minimise foreign debt percentages, inflation rates, and currency rate volatility, so improving the country's balance of payments and, as a result, its economic status. In addition, Tanzania's central bank should exercise caution in its monetary policy and take some constructive measures to control the money supply. It must keep an eye on interest rates and provide a low-interest rate in order to entice the new internal investor.

\section{REFERENCES}

Aidi, H. O., Suleiman, H. I., \& Saidu, I. A. (2018). Exchange Rate, Inflation and the Nigerian Balance of Payment. Journal of Economics and Sustainable Development, 9(3).

Alencar, D. A., \& Strachman, E. (2012). Foreign Direct Investment and Balance of Payments in Latinamerica (1990-2011).

Alexander, S. S. (1952). Effects of a Devaluation on a Trade Balance. Staff Papers-International Monetary Fund, 2(2), 263-278.

Amir, M., \& Mehmood, B. (2012). Foreign direct investment and balance of payments in Pakistan: time series evidence. Actual Problems of Economics, (136), 299-304.

Ardalan, K. (2003). The Monetary Approach to Balance of Payments: A Review of the Seminal Long-Run Empirical Research. Academy of Economics and Economic Education Research Journal, forthcoming.

Davidson, P. (1990). A post Keynesian positive contribution to "theory". Journal of Post Keynesian Economics, 13(2), 298-303.

Devereux, M. P., \& Engel, C. (2003). Monetary Policy in the Open Economy Revisited: Price Setting and Exchange Rate Flexibility. The Review Of Economic Studies, pp. 1-10.

Dohoo, I. R., Ducrot, C., Fourichon, C., Donald, A., \& Hurnik, D. (1997). An overview of techniques for dealing with large numbers of independent variables in epidemiologic studies. Preventive veterinary medicine, 29(3), 221-239.

Eita, J. H., \& Gaomab II, M. H. (2012). Macroeconomic determinants of balance of 
payments in Namibia. International Journal of Business and Management, 7(3), 173.

Frenkel, J. A., \& Johnson, H. G. (1976). The Monetary Approach to the Balance of Payments. Toronto. University of Toronto Press.

Frenkel, J. A., \& Mussa, M. L. (1985). Asset markets, exchange rates and the balance of payments. Handbook of international economics, 2, 679-747.

Hanusz, Z., Tarasinska, J., \& Zielinski, W. (2016). Shapiro-Wilk test with known mean. REVSTATStatistical Journal, 14(1), 89-100.

Imoisi, J. (2015). Exchange rate variations and balance of payment positions in Nigeria. JORIND, 13(2), 1596-1603.

Kemp, D. S. (1975). A monetary view of the balance of payments. Federal Reserve Bank of St. Louis Review, 57(Apr), 14-22.

Lin, F. J. (2008). Solving multicollinearity in the process of fitting regression model using the nested estimate procedure. Quality \& Quantity, 42(3), 417-426.

Lotfalipour, M. R., \& Bazargan, B. (2014). The impact of exchange rate volatility on trade balance of Iran. Advances in Economics and Business, 2(8), 293-302.

Melvin, M. (1992). International Money and Finance, 3rd. Edition. Harper Collins Publishers Inc., New York.

Mushendami, P., Manuel, V., Shifotoka, H., \& Nakusera, F. (2017). Empirical Analysis of the Monetary Approach to the Balance of Payment in Namibia. 3(1), 17.

Mwai, C. (2015). The effect of selected macroeconomic variables on balance of payment in Kenya (Doctoral dissertation, University of Nairobi).
Odili, O. (2014). Exchange rate and balance of payment: An autoregressive distributed lag (ARDL) econometric investigation on Nigeria. IOSR Journal of Economics and Finance, 4(6), 21-30.

Oladipupo, A. O. (2011). Impact of exchange rate on balance of payment in Nigeria. African Research Review, 5(4).

Osoro, K. (2013). Kenya's foreign trade balance: An empirical investigation. European Scientific Journal, 9(19).

Rubinfeld, D.L, R. S., Hall, B. H., \& Pindyck, R. S. (1998). TSP Handbook to Accompany Econometric Models and Economic Forecasts. McGraw-Hill/Irwin.

Sangeetha, R., \& Patni, A. (2018). Determinants of Balance of payments Evidence from India and US. International Journal of Management Studies, 5(4(6)).

Selma, Kurtishi-Kastrati, (2013). The Effects of Foreign Direct Investments for Host Country's Economy. European Journal of Interdisciplinary Studies, 5(1).

Sezgin, F. H., \& Özkan, N. N. (2015). Effect Of Foreign Direct Investment On Balance Of Payment For Turkey: Econometric Analysis. Eurasian Econometrics, Statistics and Empirical Economics Journal, 2(2), 55-75.

Shafi, K., Hua, L., Idrees, Z., \& Nazeer, A. (2015). Impact of exchange rate, inflation rate and interest rate on balance of payment: A study from India and Pakistan. American Journal of Business, Economics and Management, 3(1), 913.

Shapiro, S. S., \& Wilk, M. B. (1965). An analysis of variance test for normality (complete samples). Biometrika, 52(3/4), 591-611. 
UKEssays. (2018). Foreign direct investment and balance of payments. Retrieved from https://www.ukessays.com/essays/economics/fo reign-direct-investment-and-balance-ofpayments-economics-essay.php?vref $=1$.

Vernengo, M. (2003). Balance of payments constraint and inflation. Department of Economics of University of Utah Working Paper Series, 6.

Wallace, S. (1988). Dealing with model misspecification in the analysis of morale in old age. Open Journal of Social Sciences,

Wei, W. (2006). Vertical specialisation and accelerating poverty reduction; Achieving Inclusive Growth in China Through Vertical Specialization.

https://www.sciencedirect.com/topics/economic s-econometrics-and-finance/dickey-fuller-test

Yousaf, M., Nisan, A., \& Zakir, H. (2008). Economic Evaluation of Foreign Direct Investment in Pakistan, Pakistan Economic, and Social Review, Vol. 46, No.1, 37_56.

Yousif, F. M. K., \& Musa, A. M. A. (2017). The Determinants Factors of Balance of Payments: An Investigation from Sudan through the Period 1980-2016. American Scientific Research Journal for Engineering, Technology, and Sciences (ASRJETS), 38(1), 265-282. 